\title{
Louis Hamilton: A British Scholar in Nazi Germany
}

\author{
Grant W. Grams \\ Athabasca University \\ grantg@athabascau.ca
}

\begin{abstract}
Louis Hamilton (1879-1948) was a British national that lectured at various institutions of higher learning in Berlin from 1904-1914, and 1919-1938. During the Third Reich (1933-1945) Hamilton was accused of being half-Jewish and his continued presence at institutions of higher learning was considered undesirable. Hamilton like other foreign born academics was coerced to leave Germany because the Nazi educational system viewed them as being politically unreliable. Hamilton's experiences are an illustration of what foreign academics suffered during the Third Reich. The purpose of this article is to shed new light on the fate of foreign academics in Nazi Germany. Although the fate of Jewish professors and students has been researched non-Jewish and non-Aryan instructors has been a neglected topic within the history of Nazism.
\end{abstract}

\section{Keywords}

fascism - Aryan - foreigners - academics - intimidation - Germany - anti-Semitism Louis Hamilton (1879-1948)

Louis Hamilton (1879-1948) was a British national that had a remarkable career lecturing in Germany during the Kaiser Reich (1871 to 1918), Weimar Republic (1919-1933), and the early stages of the Nazi era (1933-1945). Between the two world wars academics in Europe, North America, private institutions, and the German government cited Hamilton as an authoritative source on Canada. ${ }^{1}$

1 National Archive of Canada (hereafter NAC) C10234 File 307724: North German Lloyd to Egan Department of Immigration and Colonization (hereafter DIC), 3 Aug. 1928; NAC C10234 File 307724: DIC to Egan DIC, 21 July, 1927; Bundesarchiv Koblenz (hereafter BAK) zsg1142-20 1922: Verein für das Deutschtum in Ausland Jahrbuch für 1922, 168; Hermann Wagner, Von Küste zu Küste: Bei deutschen Auswanderer in Kanada (Hamburg: Verlag der Ev. luth.

(C) GRAMS, 2016 | DOI 10.1163/22116257-00502005

This is an open access article distributed under the terms of the Creative Commons Attribution-

Noncommercial 4.0 Unported (CC-BY-NC 4.0) License. http://creativecommons.org/licenses/by-nc/4,0623 10:06:33AM 
Hamilton had carved out a pleasant living in Germany lecturing and teaching English yet this calm existence was disrupted by Nazism. Despite being a Germanophile, apolitical and being assimilated into German life Hamilton suffered during the Third Reich. Ultimately he was forced to migrate thus ending his career and abandoning most of his possessions. ${ }^{2}$

This article will reveal new information on non-German, non-Jewish and non-Aryan (Nazi racial concept for Germanic peoples) instructors at institutions of higher learning in Nazi Germany; the number of foreign nationals forced to leave is unknown due to the lack of research on this topic. Although the fate of Jewish professors and students has been researched non-Jewish, non-German and non-Aryan instructors has been a neglected topic within the history of Nazism. While there are some publications that note foreigners as academics that left Nazi Germany, no one has examined this topic exclusively as an area of study. To complicate this area of research there are no lists within archives that give foreign academics that suffered discrimination and departed due to fascist ideology. In order to attempt to examine this phenomenon one has to examine the materials on individual institutions, this is also problematic as primary materials are often incomplete. There are no previous studies to compare figures with, nor institutional surveys to examine or cross reference. The fact that certain individuals were born outside of Gross Deutschland [Greater Germany] dictated that their loyalty and political correctness called for greater scrutiny and examination, and unless they were gifted in their area of study and loyal to Nazism their dismissal was required. The majority of foreigners were considered unworthy of Third Reich ideals and were coerced to migrate whence they came. Certainly several dozen to several hundred foreigners, perhaps many more from across Greater Germany were forced to leave the Third Reich before World War Two. This article examines Hamilton's career from establishment of the Third Reich until he reluctantly departed in 1938 as an illustration of what foreign lecturers experienced. The purpose of this

Auswanderermission, 1929), 114-115; H.A. Innis, 'Review of Books - Deutschland und Kanada von L. Hamilton,' The Canadian Historical Review [hereafter $C H R$ ] 9 (1928): 183; W. Bausenhart, German Immigration and Assimilation in Ontario 1783-1918 (Toronto: Legas Press, 1989), 102; Agnes Rook, 'Erinnerung an Margarethe Schimank,' in Frauen in den exakten Naturwissenschaft, ed. Willi Schmidt and Christoph J. Scriba (Stuttgart: Franz Steiner Verlag, 1990), 28-29.

2 The only previous work that explores Hamilton's career is Grant Grams 'Louis Hamilton, a British Academic and Specialist on Canada in German,' Yearbook of German American Studies 43 (2008): 165-179. This present article benefits from additional German archival material and focuses on Hamilton's career from 1933-1938. 
article is to shed new light on the fate of foreign academics in Nazi Germany. Hamilton, like other non-Aryan, non-Jewish and non-German instructors, was intimidated into leaving Germany because he was deemed politically unreliable. Hamilton's case is not unique as other foreign instructors experienced injustices under Nazism after faithfully contributing to German institutions of higher learning. This article is not intended to be a complete study of foreignborn academics within Nazi Germany, it is only intended to open this topic to further analysis and scrutiny. This work will contribute to the neglected topic of foreign instructors in Nazi Germany for future research and study. ${ }^{3}$

\section{Hamilton's Early Years}

Hamilton was born in 1879 in Milton, Kent, Great Britain. He described himself as a 'student of Canadian affairs'; initially travelling to Canada in $\mathbf{1 8 9 5}$.

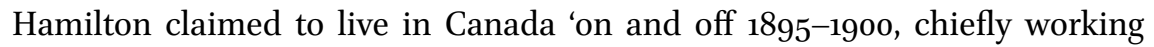
on farms in Manitoba and Eastern Townships [Quebec], also lumbering, writing, etc.; and travelled extensively throughout the country.4 $\mathrm{He}$ was formally educated in England, France, Belgium and Germany. In 1904 Hamilton was Reader in English at Friedrich-Wilhelms-Universität Berlin, now the Humboldt-Universität zu Berlin, later he was appointed Lecturer at the Technische Universität Berlin. Hamilton lectured until World War One. He spent weeks in Spandau Prison, West Berlin, but was eventually released working as a staff member for Prussian Minister of Culture for $1915^{-1918}$. He resumed his teaching career at war's end. ${ }^{5}$ Throughout his career Hamilton encouraged

3 Geheimes Staatsarchiv Preussischer Kulturbesitz (Hereafter GSPK) I RepA Nr. 66: Tgb Nr. 411 an den Minister für Wissenschaft, Kunst und Volksbildung, April 13, 1934; University of Saskatchewan Archive, Pres. Papers Series I 21 Correspondence: Louis Hamilton to [G.W.] Simpson, 6 March 1936; NAC C10234, Vol. 231, File 307724: A. O'Kelly to Egan, 3 October 1927; NAC C10234, Nr. 307724: Hamilton to DIC, London, July 11, 1927; G. Macklin, National Archive of the United Kingdom to G. Grams, 1 July 2005; Charles G.D. Roberts and Arthur L. Tunnell, The Canadian Who's Who 1937 (Toronto: Trans-Canada Press, 1938), 469; NAC C10234, Nr. 307724: Hamilton to DIC, London, 11 July, 1927; Christian Zinsser, Erinnerungen 1907-1993, Politsches Archiv des Auswärtiges Amtes, Berlin 1993, 42-43; Humboldt University Archive Nr. 73 Lektor L. Hamilton, Busch AA to Schmidt-Rolke Reichshauptkasse, May 28, 1934.

4 NAC C10234, Nr. 307724: Hamilton to DIC, London, July 11, 1927; NAC C10234, Vol. 231, File 307724: A. O'Kelly to Egan, October 3, 1927.

5 Roberts and Tunnell, The Canadian Who's Who 1937, 469; 'Notes and Comments,' The Canadian Historical Review 22 (1941): 235-236. Correspondence between Julia Hamilton to G. Grams, January 26, 2012. On November 11, 1901 Hamilton married Anna Luise Grube 
good relations between Germany and Canada specifically, and Germany and the English speaking world generally. ${ }^{6}$ By 1924 Hamilton was an English teacher and examiner for the Auswärtiges Amt [AA; German Foreign Office], Berlin. Hamilton also taught English privately at various German banks in Berlin. In addition to lecturing Hamilton conducted research and published, he was interested in Canada as a land of German emigration, travelling to Canada in 1928 for research. ${ }^{7}$ During the Weimar Republic Wilhelm Dibelius, a colleague at the University of Berlin shared an interest in Canada. Dibelius also travelled to Canada in 1928 conducting research for a book. This work was never published due to his untimely death in $1931 .{ }^{8}$ What became of this research material is unknown but Heinz Lehmann, his protégé and graduate student probably acquired Dibelius' research notes and manuscript. ${ }^{9}$ Initially Lehmann and Hamilton had a positive working relationship. In 1931 Hamilton praised the publication of Lehmann's doctorate thesis entitled 'Zur Geschichte des Deutschtums in Kanada, Das Deutschtum in Ostkanada' [The History of Germandom in Canada, The Germandom in Eastern Canada], as well as being the first general history of German speakers in Canada, Hamilton predicted, 'no one in the future, who studies the questions of Germans in Canada, will be able to without this [publication].10 Lehmann also used Hamilton as a source of information on Canada in his groundbreaking research on Canada's German speakers. Lehmann and Hamilton collectively helped others assemble material in an article dealing with German migration to Canada. Although the

producing a son Betram Alexander, which he raised after their divorce. Hamilton remarried on May 21, 1920 to Johannes Agnes Lucia Jahn; they had two children, Agnes Johanna Elizabeth and Thomas Gottfried Louis.

6 Louis Hamilton, 'Recent German Books Relating to Canada with Some Remarks on Early Pulication,' Canadian Historical Review 14 (1933): 189-198; L. Richter, 'Economics of Depression,' The Dalhousie Review 14 (1934-1935): 496.

$7 \quad$ NAC C10234, File 307724: Hamilton to DIC, 30 April 1928; NAC RG30, Vol. 624, File 3: Freer Canadian National Railway (hereafter CNR) to Devlin, August 29, 1928; Christian H. Freitag, 'Die Entwicklung der Amerikastudien in Berlin bis 1945 unter Beruecksichtigung der Amerikaarbeit staatlicher und privater Organisationen' (Diss., Freie Universitaet Berlin, 1977), 26.

8 Hamilton, 'Recent German Books,' 191.

9 Heinz Lehmann, 'Wilhelm Dibelius,' in Deutsche Arbeit (1931): 190-191; Grant W. Grams, 'Wilhelm Dibelius and his influence on German-Canadian Studies,' The German-American Yearbook (2004): 123-131.

10 Louis Hamilton, 'Review of Zur Geschichte des Deutschtums in Kanada,' CHR 13 (1932): $212-213$. 
two men initially enjoyed good relations their interactions soured dramatically during the Nazi era. ${ }^{11}$

In Germany the English language had a special appeal to German students, schools and institutions. The English language had already started replacing French as preferred foreign language during the First World War, interest in English as a foreign language broadened during the Weimar Republic. Changes were not uniform but tended to be slow and gradual amongst the various states that made up Germany, the appeal of the English language continued into the Nazi era. ${ }^{12}$ Hamilton was able to use this demand to his advantage into the early stages of the Third Reich. Although Hamilton had a normal career prior to 1933 he faced many challenges after the Nazis came to power. The Nazi government sifted out their version of the politically incorrect and unwanted elements in phases. Initially Hamilton was unaffected due to his long term residence, apolitical lifestyle and full integration into German life, although legislation was passed on April 7, 1933, which saw instructors dismissed due to inadequate training, being politically unreliable, or of non-Aryan descent. Some supposedly lost their position due to a simplification of the administrative process. This legislation was initially used to target Jews in Germany. It was later used to expel any non-Aryan throughout Greater Germany for being a threat based on potential disloyalty or lack of political reliability. ${ }^{13}$ Hamilton and other foreigners employed at the Seminar für Orientalische Sprache [sos; Seminar for Oriental Languages], part of Friedrich-Wilhelms-Universität Berlin, were asked to give information regarding their heritage including ones grandparents. Nazi qualifications such as this forced foreign instructors from their positions throughout Germany. Pressure was placed on Hamilton to declare if his four grandparents were Aryans. Hamilton deferred this question as he did not give documentation to German authorities until years later. ${ }^{14}$ Hamilton

11 Heinz Lehmann and Gerhard Bassler, The German Canadians 1750-1937 (St. John's: Jesperson Press, 1986), 474; Heinz Lehmann and Louis Hamilton, 'Das Assimilationsproblem,' in Handwörterbuch des Grenz und Auslanddeutschtum, ed. Carl Petersen, Paul H. Ruth and Hans Schwalm (Breslau: Ferdinand Hirt, 1938), 262; Freitag, 'Die Entwicklung der Amerikastudien,' 140.

12 Gerwin Strobel, The Germanic Isle (Cambridge: Cambrige University Press, 2000): 16-39.

13 Reichsgesetzblatt Teil 11933 (hereafter RGB) (Berlin: Reichsverlagsamt, 1933), 175-177; Edward Yarnall Hartshorne, The German Universities and National Socialism (London: George Allen and Unwin Ltd, 1937), 175-177; Notgemeinschaft Deutscher Wissenschaftler im Ausland, Displaced German Scholars: A Guide to Academics in Peril in Nazi Germany During the 1930's (San Bernardino: The Borgo Press, 1993), 1-4.

14 GSAP II Rep 208A Nr. 66: Vahlen, Der Reichs und preussische Minister für Wissenschaft, Erziehung und Volksbildung an Direktor des Seminars für Orientalische Sprachen, May 
continued to lecture in Berlin; it was even debated in 1934 among educational authorities if he could be given an honorary doctorate. Since Hamilton maintained his career and workload in the early years of the Third Reich it appears British academics within Nazi education were at least tolerated. The fact that he was an English language instructor also aided his career. ${ }^{15}$

Nazi ideology called for all non-Aryan elements to be weeded out of all education systems. Jewish students, teachers and professors were the first group expelled, followed by foreign born elements of a non-Aryan lineage. All foreigners were non-Aryans by designation of their non-German birth. ${ }^{16}$ For the Nazis the right of the individual was subordinate to the consensus and unity of one's blood, race, and territory. Germans had a duty to their people and country and should remain settled on the land they occupied in Europe. The strength and unity of Germany and its people must not be weakened though non-Aryans. The emigration of Jews and foreigners from Germany were a benefit to the German race and nation as their emigration meant the departure of a foreign element. The work of ingratiating students to the ideology of the Third Reich fell to the loyal Aryan citizens; foreigners could not be trusted with this mighty task. ${ }^{17}$ Adolf Hitler stated in Mein Kampf (1924) that 'the crown of

6, 1936; GSPK I Rep 208A Nr. 206: Vahlen, Preussen Minister für Wissenschaft, Kultur und Volksbildung to Direktor des Seminars für orientalische Sprachen, September 16, 1933; Direktor des Seminars für orientalische Sprachen to Minister für Wissenschaft, Kultur und Volksbildung, September 22, 1933. GSPK I Rep 208A Nr. 66: H.F. Purt to Reichs und Preuss. Minister, May 17, 1934

16 Bela Bodo, 'Foreign Students in Nazi Germany, East European Quarterly 37 (2003): 19-42; Bela Bodo, 'The Role of Anti-Semitism in the Expulsion of non-Aryan Students, 19331945,' Yad Vashem Studies 30 (2004): 191-225; Hans Ebert, 'The Expulsion of the Jews from the Berlin-Charlottenburg Technische Hochschule,' Leo Baeck Institute Year Book 19 (1974): 158-168; Klaus Fischer, 'Repression und Privilegierung: Wissenschaftpolitik im Dritten Reich,' in Im Schungel der Macht: Intellektuelle Professionen, ed. Dietrich Beyrau (Göttingen: Vandenhoeck und Ruprecht, 2000), 170-171; Arye Carmon, 'The Impact of the Nazi Racial Decrees on the University of Heidelberg,' Yad Vashem Studies 11 (1976): 131-136, 163; Albert Hourani, 'The Formation of a Scholar, the Stages on my way,' British Journal of Middle Eastern Studies 18 (1991): 159-166.

17 Kurt Welz, Die Regelung der Ein- und Auswanderung als verfassungsrechtliches Problem (Jena: Büro Hellas, 1940), 76-9o; Jonathan Wagner, Troubles in Paradise: Letters to and From German Immigrants in Canada 1925-1939 (St.Katharinen: Scrita Mercaturae Verlag, 1998), 243-244; PAAA R127492 Kult E Reichstelle für das Auswanderungswesen Band 3: Staatssekretär Frhr von Weizsäcker [der AO] an [AA] Kult E, Berlin December 11, 1939; Michael Grüttner, 'German Universities under the Swastika,' in Universities under Dictatorship, ed. Michael Grüttner and John Connelly (University Park, PA: Pennsylvania University Press, 2005), 91. 
the folkish state's entire work of education and training must be to burn the racial sense and racial feeling into the instinct and the intellect, the heart and the brain of the youth.'18 Although Hitler and Nazi ideology stressed the similarities between the German and English peoples, non-Aryans and foreigners were not to be placed in positions of authority, including those at institutions of higher learning. ${ }^{19}$

\section{Applying Pressure on Foreign Instructors}

On January 9, 1935 foreign instructors in the Reich needed to be approved by German authorities in order to resume teaching. It needed to be assessed if foreign born lecturers were compatible with Nazi cultural policies and could properly educate Aryan students. Investigations were conducted, if needed the German Foreign Office would be called upon to obtain information and help in passing a judgement. This was indeed the case with Hamilton. ${ }^{20}$ Nazi legislation continued as another law was passed on January 21, 1935 allowing the transfer, and removal of professors based on the termination of academic positions. ${ }^{21}$ The Nuremberg Citizenship laws of November 1935 further curtailed academic life. ${ }^{22}$ Nazi Germany became increasingly critical and sceptical of all things foreign. The training of future Germans needed to be accomplished by those deemed worthy and honourable, hence unknown elements including foreign born instructors needed to be weeded out if Germans were to forge a homogenous nation through unity. ${ }^{23}$ Hamilton was again asked to supply information on his grandparents in 1935. He did not fulfil this request, yet he continued to lecture. ${ }^{24}$ From 1933 to 1936 German universities saw the removal of Jewish professors initially followed by 'politically unwanted' university

\footnotetext{
18 Adolf Hitler, Mein Kampf (London: Pimlico, 2008), 389.

19 Gerhard L. Weinberg, Hitler's Second Book: The Unpublished Sequel to Mein Kampf (New York: Enigma Books, 2003), 160-173; Gerwin Strobl, The Germanic Isle: Nazi Perceptions of Britain (Cambridge, 2000), 36-49

20 E.Y. Hartshorne, 'German Universities and the Government,' Annals of the American Academy of Political and Social Sciences 200 (1938): 218; Edward Yarnall Hartshorne, 'The German Universities and National Socialism' (Diss., University of Chicago, 1938), 6-9.

$21 \quad$ RGB 1935 Teil $I, 23-24$.

22 Ibid., 1145-1147, 1333-1334.

23 A. Wolf, Higher Education in German Occupied Countries (London: Methuen and Co., 1945), 1-6.

24 GSPK Direktor Mittwoch to Verwaltungs Direktor bei der Friedrich-Wilhelm Universität, December 6, 1935 .
} 
personnel. Hamilton was not politically active and did not oppose the Nazis but his non-compliance to fill out the required paperwork on his ancestry dictated that his case be placed under greater scrutiny. His lack of compliance marked him as a plausible enemy that needed to be expelled. ${ }^{25}$ By late 1935 Hamilton was growing uncomfortable with his position in Germany and inquired about the possibility of teaching in Canada. ${ }^{26}$ Nazi bureaucratic pressure intensified in 1936 as Hamilton found administrative hurdles arbitrarily placed in front of him. On October 31, 1936 Hamilton learned he would not be allowed to teach in the upcoming semester, just two days before it began. Hamilton felt demoralized through persecution with slander and gossip aimed at him to discredit his career that he had forged over decades. Regardless of the source, or truth it culminated in ruining him and negatively affecting his family. ${ }^{27}$ By 1936 after Jewish instructors had been dismissed foreign instructors felt increasingly isolated and unwanted. ${ }^{28}$ Supplements of the 1933 law were added through the next four years with the final edict issued on January 26,1937 . These laws although aimed at ridding Germany of Jewish professors affected all non-Aryans including foreign academics, such as Hamilton. ${ }^{29}$ Hamilton lost his position teaching English in the AA. He lamented that after serving Prussia for thirty-two years; at the age of fifty-seven he was ruined. ${ }^{30}$

It appears that foreigner academics that taught English enjoyed a lower level of enquiry owing to the fact that the English language was to be the first foreign language learned at pre-University levels in German schools. ${ }^{31}$ By

25 Grüttner, 'German Universities under the Swastika,' 88-93; Christopher M. Hutton, Race and the Third Reich (Cambridge: Polity Press Cambridge, 2005), 90-92.

26 University of Saskatchewan Archive, Papers Series I 21 Correspondence: G.W. Simpson to L. Hamilton, February 20, 1937; University of Saskatchewan Archive, Board of Governors Executive Minutes: Minutes of a Meeting of the Executive Committee of the Board of Governors of the University of Saskatchewan, Held in Dr. Murray's Office on February 25, 1937; University of Saskatchewan Archive, Pres. Papers Series I 21 Correspondence: L. Hamilton to Walter C. Murray, President of the University of Saskatchewan, April 16, 1937.

27 GSAP I Rep 208A Nr. 68: Hamilton to Reichs und preussische Minister für Wissenschaft, Erziehung und Volksbildung, November 9, 1936.

28 Max Weinrich, Hitler's Professors: The Part of Scholarship in Germany's Crimes against the Jewish People (New York: Yiddish Scientific Institute, 1946), 19.

29 RGB 1937 Teil II, 41-70.

30 GSAP I Rep 208A Nr. 66: Hamilton to Leiter der Auslandhochschule Scharschmidt, January 17, 1937.

31 Reiner Lehberger, Englischuntericht im Nationalsozialismus (Tübingen: Stauffenburg, 1986), 70-72; Harald Scholtz, Erziehung und Unterricht unterm Hakenkreuz (Goettingen: Vandenhoeck und Ruprecht, 1985), 6 o. 
1937 the Nazis made English the first foreign language to be taught replacing French and other romance languages reasoning that English was Germanic and a language of a Northern race that was relevant to Nazi ideals, ${ }^{32}$ while other languages were incompatible to Germanic culture. ${ }^{33}$ With English being the first foreign language learned by students, teachers of English such as Hamilton were initially tolerated in the first phase of the Nazi education system. The English and their language were viewed 'as Germanic brothers, or in the light of the Celtic substratum, at least as cousins. ${ }^{34}$ It also appears that western Europeans were also treated somewhat better than their compatriots from Eastern Europe during the Third Reich. ${ }^{35}$ During the Nazi era the emphasis on learning English as a foreign language only increased. ${ }^{36} \mathrm{Al}-$ though Frank-Rutger Hausmann noted many English scholars were 'victimized' during the Third Reich. This process also occurred within other areas of academic life. ${ }^{37}$

Higher education in Germany changed after 1933 as its goal now was to mould obedient and loyal National Socialists. Generally foreign teachers and professors were deemed too liberal and therefore incompatible with Nazi

32 Ulrich Ammon, 'Language Conflicts in the European Union,' International Journal of Applied Linguistics 16, no. 3 (2006): 323; Hans F.K. Guenther, 'The Nordic Race as "Ideal Type",' in Nazi Culture: Intellectual,Ccultural, and Social Life in the Third Reich, ed. George L. Mosse(New York: Grosset and Dunlap, 1966), 61; Ulrich Ammon, 'The European Union (EU - formerly European Community) Status change of English during the last fifty years,' in Post-Imperial English Status Change in Former British and American Colonies, 1940-1990, ed. J.A. Fishman, A.W. Conrad and Arubal-Lopez (New York: Mouton de Gruyter, 1996), 250; George Frederick Kneller, The Educational Philosophy of National Socialism (London: Yale University Press, 1941), 212.

33 Kneller, The Educational Philosophy of National Socialism, 212-214; I.L. Kandel, The Making of Nazis (Westport: Greenwood Press Publishers, 1935), 95; Wolfgang Keim, Erziehung unter der Nazi-Diktatur, Band II (Darmstadt: Wissenschaftliche Buchgesellschaft, 1997), $38-39$.

34 Frank-Rutger Hausmann, 'English and Romance Languages in Germany's Third Reich,' in Nazi Germany and the Humanities, ed. W. Bialas and Anson Rabinbach (Oxford: Oneword Publications 2007), 345.

35 Ulrich Herbert, Hitler's Foreign Workers: Enforced Foreign Labor in Germany under the Third Reich (Cambridge: Cambridge University Press, 1997), 97-131; Diemut Majer, Non-Germans under the Third Reich (Baltimore: John Hopkins University Press, 2003), 62.

36 Ingrid Harkes-Hanke, 'Die Aufnahme des fremdsprachlichen Unterrichts in die allgemein Lehrplaene des westdeutschen un der Berliner Volkshochschule 1945-1948' (Diss., Freie Universität Berlin, 1981), 29.

37 Hausmann, 'English and Romance Languages in Germany's Third Reich,' 350-352. 
ideology. ${ }^{38}$ Ziemer noticed at the University of Berlin the emphasis on learning had declined with emphasis in favour of physical education and dedication to Nazi ideology. The German education system was to be used to forge obedient Nazis; German universities became part of the indoctrination process. ${ }^{39}$ Hartshorne assessed the impact of the Nazis on German education. He witnessed losses in all aspects of German learning. Hartshorne noted that the University of Berlin lost nearly a third (32.4\%) of their academic teaching staff between 1933 and 1936, a total of 242 of its faculty. Many learned and professional men were driven from academia with less qualified and academically mature Nazi instructors inserted in their place causing problems. ${ }^{40}$ Hamilton would not be included in Hartshorne's figures as he remained in his position until 1938. Therefore the actual number for the University of Berlin, and figures throughout Germany would have been higher based on the late departure of Hamilton and others. ${ }^{41}$

\section{Hamilton and his 'Jewish Origins'}

Pressure had also mounted against Hamilton as accusations were made that his correct name was actually Louis Hamilton Silberberg. Administrator H.F. Purt noted that rumours that 'L. Hamilton, was of Jewish descent and actually was named Silberberg, or Silberstein were around for a long time. I never had the opportunity to determine if these were true. Five or six years ago I asked Mr. Hamilton directly about these rumours. He evaded giving an answer to the question. Because his case is not unique, I therefore believe it is very important

38 Anon., Education in Nazi Germany (London: Kulturkampf Association, 1938), 1-20, 46-55; George F. Kneller, Foundations of Education (New York: John Wiley and Sons, 1963), 181184; Pierre Aycoberry, The Social History of the Third Reich 1933-1945 (New York: The New Press, 1998), 133-139; Robert Cecil, Education and Elitism in Nazi Germany (London: Institute for Cultural Research, 1971), 3-6; Lisa Pine, Education in Nazi Germany (New York: Berg, 2010), 34-35.

39 G. Zeimer, Education for Death: The Making of the Nazi (New York: Oxford University Press, 1941), 171-177.

40 Hartshorne, The German Universities and National Socialism, 87-105, 126-174.

41 Eva Dreschler, Geheimes Staatsarchiv Prüssischer Kulturbesitz, to G. Grams, April 11, 2007; Hartshorne, The German Universities and National Socialism, 94; Charles G.D. Roberts, The Canadian Who's Who 1938-1939 (Toronto: Trans-Canada Press, 1940), 298-299; Carmon, 'The Impact of the Nazi Racial Decrees,' 143. 
to know if these foreigners that we employ are Jews. ${ }^{32}$ Eventually forms filled out by Hamilton declared that his father's name was unknown because he was an illegitimate child. Nazi officials scoffed that he did not know his father's name as earlier correspondence and administrative documents haunted Hamilton. In 1904 Hamilton had hurriedly left Germany for London due to the illness of his father. There were three letters and one telegram from Hamilton while he was in London in 1904 which stated that Louis Silberberg, a Jewish tobacconist was his father. ${ }^{43}$ Yet in the 1930s Hamilton denied this accusation maintaining that Silberberg was merely a surrogate father, not his biological father, although he firmly believed he was his father. ${ }^{44}$ Nazi officials incessantly referred to Hamilton's correspondence written to university administrators in 1904 stating he was in London to visit his dying father. His correspondence from July 26, 1904 stated that he was 'compelled to be in England for a few days through my fathers' illness'. He noted that 'having had to come here [London] suddenly, my father being in a most critical condition', Silberberg died on July 27, 1904. By 13 August 1904 Hamilton had returned to Berlin. Documentation from Hamilton throughout 1904 stated that Louis Silberberg was his father. ${ }^{45}$ No father's name was given on his birth certificate, but on the 1881 England and Wales Census for 1881 Hamilton is listed as the son of Louis Silberberg. Although the exact nature of this relationship will not be fully known this ambiguous connection haunted Hamilton during his residence in Nazi Germany. ${ }^{46}$

In 1936 when confronted by Nazi officials Hamilton defended himself by stating that the 'death certificate from Mr. Silberberg states my name as [Louis] Hamilton Silberberg because I was called this at the time, and I held him to

42 GSPK H.F. Purt to Reichs und Preuss Minister für Wissenschaft, Erziehung und Volksbildung, January 15, 1936.

43 BA(в)rch R4901/13265: Administration form, approx. 1937; GSAP II Rep 208A Nr. 66: Vahlen, Der Reichs und preussische Minister für Wissenschaft, Erziehung und Volksbildung an Direktor des Seminars für Orientalische Sprachen, May 16, 1936. GSAP II Rep 208A Nr. 66: L. Hamilton to Leiter A.H. Palme, June 12, 1936; GSAP II Rep 208A Nr. 66 : L. Hamilton to Reichs und preussische Minister für Wissenschaft, Erziehung und Volksbildung, November 1, 1936; GSAP II Rep 208A Nr. 66: Vahlen, Reichs und preussische Minister für Wissenschaft, Erziehung und Volksbildung to kommissarischen Leiter des Auslandshochschule an der Universität Berlin, November 20, 1936.

45 GSAP I Rep 208A Nr. 68: Telegraphie des Deutschen Reichs, Hamilton to Dr. Sachau, July 26, 1904;; GSAP I Rep 208A Nr. 68: Hamilton to Dr. Sachau, July 26, 1904; 'Deaths', The Times, July 29, 1904, 1.

46 Person details for Louis Hamilton in household of Louis Silberberg, accessed August 19, 2014, https://familysearch.org/. 
be my father. That he was not my father I only experienced from the mouth of my mother after the death of Mr. Silberberg. ${ }^{47}$ Nazi officials found it hard to believe that his mother had a child from another man, and then Silberberg volunteered to raise the child as if it was his own offspring. Regardless of the identity of his father Hamilton contends that Silberberg was not Jewish, but a Christian buried in a protestant graveyard. ${ }^{48}$ But Hamilton had lied to Nazi authorities as research reveals Louis Silberberg as a practicing Jew. This fact would have been known to Hamilton and his mother. ${ }^{49}$ Unknown to Nazi authorities in 1895 Hamilton, age fifteen migrated to Canada giving his name on this voyage as Louis Silberberg. It appears that he altered his name to Hamilton prior to establishing residence and starting a career in Germany. If this fact would have been known to Nazi officials it would have expedited his dismissal from Germany. ${ }^{50}$

The combination of Nazi legislation and the enhanced rank the English language held within Nazi education made English more widely learned during the Third Reich, initially its instructors were tolerated. But as Nazism became more firmly entrenched it also led to increased scrutiny of who taught Aryan students. This culminated in more and more pressure being placed on Hamilton to prove his roots. ${ }^{51}$ Hamilton correctly assessed that he was being driven out of his teaching positions; he had witnessed other foreign-born instructors being hounded out of Germany. Although the exact number is not known Hamilton personally knew of several foreign-born instructors that were being forced from their positions. Most of these individuals taught foreign languages similar to Hamilton, but how many might have been dismissed from the entire university is unknown. How many that were let go throughout Germany is also open to speculation. Foreign lecturers were regarded as undesirable and incompatible with Nazi Germany's cultural policy, this coincided with them being deprived of their rights and eventually being bullied into leaving the country. Hamilton contended that his situation would be different. He vowed

47 GSAPk I Rep2o8A Nr. 66: Hamilton to Palme, June 12, 1936

48 GSAP I Rep 208A Nr. 66: Hamilton to Palme, Direktor des Seminars für Orientalische Sprache, May 15, 1936; GSAP I Rep 208A Nr. 66: kommissarische Leiter der Auslandshochschule to Reichs und Preuss. Minister für Wissenschaft, Erziehung und Volksbildung, November 2, 1936; GSAP I Rep 208A Nr. 66: L. Hamilton to Palme, December 6, 1936

49 Petra Laidlaw, An index of the Jewish community in the British Isles in 1851 (2010), 646; 'Deaths,' 1. Silberberg's funeral occurred at Willesden New Cemetery, London.

50 NAC RG76 C4516 Passenger Lists 1865-1922: Schedule A, Liverpool to Halifax, April 1, 1895.

51 BAB R4901/21630: Palme Auslandshochschule to Reichs und Preuss. Minister für Wissenschaft, Erziehung und Volksbildung, April 15, 1937. 
that he would contact the British Embassy in Berlin for protection. Hamilton also stated that he knew Joachim von Ribbentrop (German Ambassador for the United Kingdom, 1936-1938), he would complain to this well placed Nazi and seek protection and help. It is unknown if he contacted these sources but nothing relented in the pressure against him. ${ }^{52}$ Ribbentrop spent 1910-1914 in Canada. Based on his position within the German foreign office and his years in Canada combined with Hamilton's knowledge on Canadian affairs and teaching English in the German foreign office, the two men could have had some level of interactions and knowledge of the other but there is no tangible proof that the two men met. ${ }^{53}$

Some of the pressure placed on Hamilton was exerted by Anton Palme. In 1933 Palme had become a member of the NSDAP (no. 2583188), in August 1935 he then became the Director of the Auslandshochschule (the Seminar for Oriental Languages became the Auslandshochschule in 1935). Palme was also a member of the Sturmabteilung [sA; Storm Detachment] having the title of Scharführer [squad leader]. He was an enthusiastic Nazi advocating proper policy whenever he believed Nazi racial theory was needed. He acquired more and more power and in 1936 actively worked to have undesirable elements, including Hamilton barred from employment within the Third Reich. ${ }^{54}$ Palme revelled in his new authority and he enjoyed questioning Hamilton. Palme allegedly noted that Hamilton confided in him how he came to his well state of being in Berlin. Although Hamilton held teaching positions at the Auslandshochschule, Technical Hochschule, the Auswärtiges Amt and various German banks his

52 Hartshorne, 'The German Universities and the Government,' 218-219; GSAP I Rep 208A Nr. 66: Hamilton to Palme, Direktor des Seiminars für Orientalishce Sprache, May 15, 1936; GSAP I Rep 208A Nr. 66: kommissarische Leiter der Auslandshochschule to Reichs und Preuss. Minister für Wissenschaft, Erziehung und Volksbildung, November 2, 1936.

53 Michael Bloch, Ribbentrop (New York: Crown Publishers, 1992), 6-8; John Weitz, Hilter's Diplomat: Joachim von Ribbentrop (New York: Tichnor and Fields, 1992), 12-16; Robert Lawson, 'Ribbentrop in Canada 1910-1914: A Note,' International History Review 29, no. 4 (2007), 821-832; James Barnes and Patience Barnes, Nazis in Pre-War London 19301939 (Brighton: Sussex Academic Press, 2005), 85-90.

54 Ursula Wokoeck, German Orientalism the study of the Middle East and Islam from 18001945 (New York: Routledge, 2009), 206; BAB R4901 Nr. 20027: Reichs und Preuss. Minister für Wissenschaft, Erziehung, und Volksbildung. September 23, 1937; вAB R4901/1587: Palme, Direktor für Orientalische Sprachen an Reichs und Preussischen Minister für Wissenschaft, Erziehung und Volksbildung, December 4, 1935; Gideon Botsch, Politische Wissenshaft im Zweiten Weltkrieg: Die 'Deutschen Auslandswissenschaften' im Einsatz 19401945 (Paderborn: Ferdinand Schoeningh, 2006), 40-47. Palme was born on September 18, 1872 in Posen, he married in 1901. 
wealth came from his mother; he was the only living child, while another part of this wealth came from Silberberg. According to Palme, Hamilton's second marriage had been advantageous as he intentionally wed a wealthy woman. ${ }^{55}$ Due to Hamilton's clandestine parentage Palme became increasingly dogged regarding his undeclared status. He referred persistently to Hamilton's 1904 correspondence when he wrote that Silberberg was his father, but now Hamilton stated he was not his father. According to Palme this contradiction and ambiguity alone dictated that Hamilton should be dismissed. In addition Louis Silberberg death certificate that was acquired by the German embassy in London stated that Louis Hamilton Silberberg was his son. More problems surfaced for Hamilton as Palme recollected conversing with Hamilton about rumours of his Jewish roots in 1929 or 1930. According to Palme Hamilton quickly changed the subject with a nervous laugh. When asked about Silberberg he did not state he was not his father. Palme concluded that Hamilton's stories about Silberberg's religious background were not to be believed. Another fact raised by Palme was that in 1904 Hamilton wrote that his first wife Anna Luise (nee Grube) from London, in this correspondence he never mentioned the sudden revelation of Silberberg not being his true father. Another factor for Palme was that during Hamilton's divorce procedure with his first wife the fact emerged that Hamilton had Jewish ancestors. Palme doubted his mother told him only after the death of Silberberg that he was not his father. Palme correctly noted that any person could claim that a dead mother revealed something. He asserted that English studies at an institution of higher learning were being contaminated if Hamilton had influence over the flower of German youth as his Jewish taint was unwanted. ${ }^{56}$

Throughout the Nazi era Hamilton witnessed academics being corrupted by Nazi ideology while reaping promotions and scholarly rewards. One example was Heinz Lehmann. Hamilton found Lehmann's 1935 article entitled 'Das evangelische Deutschtum in Kanada' [The Lutheran Germandom in Canada] a case of academic corruption as Lehmann repeated concepts of Aryan superiority. Hamilton recorded that 'it requires restraint to read and write about Herr Lehmann's studies without a feeling of irritation released by his patronizing tone toward Canadians, traces of Anglophobia, and more than a modicum of that modern method of disseminating information and ideas derived from the

55 GSAP I Rep 208A Nr. 66: Palme, Leiter der Ausland-Hochschule to Reichs und Preuss. Minister für Wissenschaft, Erziehung und Volksbildung, July 24, 1937.

$5^{6} \quad$ Ibid., September 6, 1937. 
congregatio de propaganda fide. ${ }^{57}$ Certainly Lehmann advanced as Hamilton was being oppressed and ostracized as a non-Aryan. By 1936 Lehmann was lecturing in the same department as Hamilton, and grew ever more comfortable within the same nazified institution of higher learning. ${ }^{58}$ Lehmann had become a Nazi party member in 1933 accepting Nazi ideology while benefitting from its policies within academia, certainly Lehmann's career opportunities grew as he complied with Nazi wishes. Lehmann was like other Germans gaining a better position and increased social mobility by taking advantage of Nazi racial policies. ${ }^{59}$ According to Hamilton, Lehmann's outlook was saturated with Nazi ideology as his writings contained

dangerous and mendacious glorification of the German elements in Canada, with its sneers, accusations and distorted figures. Few realize the dangerous influence of such books. Parenthetically be it remarked that at German Universities all teachers (Lehmann is one) whose subject was Canada, the United States, or England, etc., were expected to run down that particular country and its people, and to make them the object of hate and derision. The Nazi theory is that only he who hates a foreign country is fit to teach its language or impart information about it. This was officially called Feindkunde (knowledge of the enemy). ${ }^{60}$

In mid-1937 Nazi authorities officially placed Hamilton on 'sabbatical' until his racial status was clarified.61 This status was reversed for unknown reasons

57 Louis Hamilton, 'Review of Das evangelische Deutschtum in Kanada von Dr. Heinz Lehmann,' CHR 17 (1936): 344-345.

58 Lehmann and Bassler, The German Canadians, XXIV-XXvıII; Gunta Haenicke and Thomas Finkenstaedt , Anglistenlexikon: 1825-1990: Biographische und bibliographische Angaben zu 318 Anglisten (Augsburg: Universität Augsburg, 1992), 188-19o. Bassler claimed that Lehmann's publication 'Das Deutschtum in Westkanada' [The Germandom in Western Canada] was free of Nazi ideology and represented a neutral account of German speakers in Canada.

59 Heinz Lehmann, Englands Spiel mit Polen: Die englisch-polnischen Beziehungen seit dem Weltkriege (Berlin: Junker und Dünnhaupt Verlag, 1940), 5-46; Botsch, Politische Wissenschaft im Zweiten Weltkrieg, 270; Götz Aly, Hitler's Beneficiaries: Plunder, Racial War, and the Nazi Welfare State (New York: Henry Holt and Co, 2007), 16-72, 320-322; Götz Aly, Why the Germans? Why the Jews? (New York: Henry Holt and Co, 2011), 168-172.

6o Louis Hamilton, 'Canada as seen from "the other side", The Dalhousie Review 25 (1945/46): 407-409.

61 Humboldt University Archive Nr. 73 Lektor Louis Hamilton: Groh, kommissarische Leiter der Auslandshochschule to Reichs und Preuss. Minister für Wissenschaft, Erziehung und Volksbildung, June 17, 1937. 
allowing Hamilton to teach in the fall of 1937 but this would be his final semester teaching in Germany. ${ }^{62}$ Throughout this time period Hamilton grew increasingly uncomfortable with his position in Germany and made inquiries at the University of Saskatchewan located in Saskatoon, Saskatchewan. The university welcomed the idea of Hamilton teaching at their institution. Owing to financial and administrative challenges of the Great Depression the University of Saskatchewan was creative in finding a position for Hamilton. It was anticipated that Hamilton would teach English and History at the university, possibly through adult extension classes. It was also proposed that Hamilton could also lecture in North Battleford (129 km from Saskatoon) and Prince Albert (141 km from Saskatoon). Work could also be found for him correcting essays, exams, etc. for other professors. ${ }^{63}$ Hamilton arrived in Montreal in mid-June 1937 bringing with him furniture, books, and lecture materials. All materials were destined for Saskatoon with no reference made of Hamilton's wife or family. ${ }^{64}$ His family status at this time in unknown; undoubtedly Nazi intrusions on his life put a strain on this relationship. Johanna Hamilton, Louis' wife gave testimony that she was separated from her husband Louis, whether this was a fact, or fabricated to fend off Nazi authorities is open to speculation. Hamilton taught during the summer of 1937 in Saskatoon but returned to Germany during the fall, but he intended to return to Saskatoon during the summer of 1938. Although Hamilton was grateful for the opportunity at the University of Saskatchewan, he was disappointed to be travelling in order to teach, and expressed disdain at correcting other professor's work. He wanted to be a university lecturer, not an assistant. His reasoning being that 'the extra-mural

62 GSAP I Rep 208A Nr. 66: Wacher, Reichs und Preuss. Minister für Wissenschaft, Erziehung und Volksbildung to Leiter der Auslandshochschule, August 7, 1937; GSAP I Rep 208A Nr. 66: Groh, Reichs und Preuss. Minister für Wissenschaft, Erziehung und Volksbildung to Leiter der Hochschule an der Universität Berlin, June 9, 1937; Clemens Scharschmidt, ed., Mitteilung der Ausland-Hochschule an der Universität Berlin (Walter de Gruyter and Co, 1938), II.

63 University of Saskatchewan Archive, Papers Series I 21 Correspondence: G.W. Simpson to L. Hamilton, February 20, 1937; University of Saskatchewan Archive, Board of Governors Executive Minutes: Minutes of a Meeting of the Executive Committee of the Board of Governors of the University of Saskatchewan, Held in Dr. Murray's Office on February 25, 1937; University of Saskatchewan Archive, Pres. Papers Series I 21 Correspondence: L. Hamilton to Walter C. Murray, President of the University of Saskatchewan, April 16, 1937; GSAP I Rep. 208A Nr. 66: Unknown to Rektor Technischen Hochschule Berlin, September 23, 1937.

64 NAC C10234 Vol. 321 File 307724: W. Black to R.B. Maxwell, June 15, 1937; NAC C10234 Vol. 321 File 307724: [DIC] Memo, June 23, 1937, NAC C10234 Vol. 321 File 307724: Canadian Immigration Service [Form], stamped 21 June 1937. 
work could be done better by a younger and unmarried man who is not engaged in writing and tied to a library, nor who would mind the loss of time and opportunities to work, as well as roughing it entailed by continual travelling, irregular meals and stays in 'bum' hotels.' ${ }^{65}$ Hamilton intended to leave Nazi Germany by April 1938 accompanied by his entire family. While finding the atmosphere in Berlin inhospitable due to the Nazification of the German educational system Hamilton did not return to Saskatoon, ${ }^{66}$ instead Hamilton and family migrated to England. Hamilton like other instructors sought a new life away from the oppressive measures dictated by German fascism. ${ }^{67}$

\section{Hamilton Leaves Germany}

By May 1939 forty-five per cent of the teaching staff at institutions of higher learning in Germany had been replaced by Nazi instructors. ${ }^{68}$ Although Hamilton departed from Germany prior to the Second World War, he was not the only foreigner teaching in Berlin that had problems with the Nazi administration. One comparable example of an instructor of higher education being coerced out of a teaching position is Cyprien Francillon. Francillon was a native speaker of French, after his education he moved to Berlin in April 1901 to teach French at the sos. ${ }^{69}$ Like all foreign instructors he had to declare his racial origin during the Nazi era, unlike Hamilton he filed this paperwork in 1933. His racial origin was in order and his career continued. But in 1936 he encountered problems as Francillon was accused of tax evasion, ordered to pay 5000RM, and barred from lecturing in Germany. Whether this accusation is true is unknown but the Nazi administration colluded against him. Francillon complained bitterly that after thirty-five years of teaching at institutions

65 University of Saskatchewan Archive, Pres. Papers Series II, A-22: L. Hamilton to President [Murray], November 14, 1937.

66 University of Saskatchewan Archive, J.E. Murray Papers MG67 IA III: L. Hamilton to Dr. Murray, November 14, 1937; University of Saskatchewan Archive, Pres. Papers Series II, A-22: President [Murray] to L. Hamilton, November 30, 1937.

67 'Notes and Comments,' Canadian Historical Review 11 (1941): 235.

68 A.Wolf, Higher Education in Nazi Germany (London: Methuen and Co, 1944), 30-31.

69 Humboldt University Archive, Personal Akten Nr. 107 Cyprien Francillon - Personalnachrichten; PAAA 139638: Althoff, Der Minister der geistlichen p. Angelegenheiten to Direktor des königlichen Seminar für Orientalische Sprache, July 27, 1904. Francillon was born October 14, 1874 in La Chapelle de la Tour, France. Periodically Francillion is spelled with a second 'i', it has been consistently deleted here. 
of higher learning in Berlin, at the age of sixty-two he could no longer teach in the Reich. Francillon was separated from his wife, but their divorce and her accusations only fuelled the administration's unfair conduct. Francillon also noted that his supposed tax evasion had been reported in three different daily newspapers in Berlin adding to his embarrassment. He was also accused of being an enemy of Germany (Deutschfeindlichkeit). Francillon lost his pension despite the fact that other foreign lecturers that had been recently barred from teaching were able to retain their German retirement fund. Due to being forbidden from employment in Germany, Francillon returned to France while his estranged German wife received his pension. ${ }^{70}$

In contrast to Hamilton and Francillon some foreign-born professors remained in Nazi Germany throughout the Third Reich. These individuals were talented, accepted Nazi ideology and conformed to the status quo. ${ }^{71}$ Although Hamilton left Germany prior to World War II other foreigners continued to teach throughout the war. Francis Stewart, an Irish nationalist was an individual who gained from Hamilton's departure. Stewart had been invited to give a series of lectures as a tour in Germany by the German Academic Exchange Office in February 1939. While in Berlin he met members of the Auslandshochschule. His time in Berlin and the desire for a native speaker of English matured into an offer of a well paid lecture position at the English Seminar in late 1939. Francis lectured on Anglo-Irish literature, but also advised the German Foreign Office on matters relating to Ireland. Periodically he addressed Ireland on radio broadcasts. Stuart remained for the duration of the war. Similar to Lehmann, Stuart also gained from Hamilton's departure. ${ }^{72}$

$70 \quad$ BAB R4901 Nr. 17474: Verw. Dir b.d. Univ.Berlin, April 21, 1933; BAB R49o1 Der Reichs und Preuss Minister für Wissenschaft, Erziehung und Volksbildung, und Reichsminister der Finazamt, August 10, 1936; Cyprien Francillon to Minister für Wissenschaft, Erziehung, und Volksbildung, September 18, 1936; вав R4901 Nr. 17474: Cyprien Francillon to Reichminister der Finanzen, September 15, 1936; BAB R4901 Nr. 17474: Cyprien Francillon to Reichminister der Finanzen, November 25, 1936; вав R4901 Nr. 17474: Preussische Staatsministerium to Reichs und Preussische Minister für Wissenschaft, Erziehung, und Volksbildung, February 5, 1937; BAB R4901 Nr. 17474: Panzer, Geographisches Institut, Heidelberg to Reichs und Preussische Ministerium, Erziehung, und Volksbildung, February 2, 1937; PAAA R64167 Nr. 7450: Francillon to Minister für Wissenschaft, Erziehung, und Volksbildung, November 30, 1936; PAAA R64168 Nr. 7450: Mina Schlunk to Kultur Minister, January 29,1937 .

71 Weinrich, Hitler's Professors, 19

72 J.H. Natterstad, Francis Stuart (Lewisburg: Bucknell University Press, 1974), 53-66; Brenda Barrington, ed., The Wartime Broadcasts of Stewart Francis 1942-1944 (Dublin: Lilliput Press, 200o), 28-34; Enno Stephan, Spies in Ireland (London: MacDonald Press, 
Constantin Carathéodory, a Greek national also remained in Germany throughout the war. Carathéodory studied mathematics at the University of Berlin in 190o. In 1902 he studied at the University of Göttingen, receiving his Ph.D. in 1904. In 1924 he was appointed Professor of Mathematics at the University of Munich. During the Nazi era he was classified as an Aryan and remained in his academic position until he retired in 1938. He continued to be an active researcher at the university and at the Bavarian Academy of Science. As an international authority on mathematics his reputation and presence in Nazi Germany brought the Third Reich prestige and acceptance at international meetings and missions. ${ }^{73}$ Another foreigner academic that was allowed to stay was Jusuf Ibrahim; he was born in Egypt as the son of an Egyptian doctor and German mother. He was educated in Berlin as a medical doctor specializing in gastrointestinal diseases in newborns and central nervous system irregularities in children. He became a professor of paediatrics at the University of Jena remaining in his profession throughout the war. He supported the Nazi system taking an accommodating role in the Nazi euthanasia program. ${ }^{74}$

Although some foreigners remained others were coerced into leaving nazified institutions of higher learning. Peter Joseph Wilhelm Debye was Dutch, he studied physics in Germany. Debye established a good reputation in Germany as a scientist and in 1935 he was appointed as Director of the Kaiser Wilhelm Institute for Physics in Berlin. In his position he faced pressure from Nazi students and Reich officials but based on his German education and reputation established prior to the Nazi ascension to power he remained in his position.

1963), 78-97; Horst Dickel, Die Deutsche Aussenpolitik und die irische Frage von 1932-1944 (Wiesbaden: Franz Steiner Verlag, 1983), 106-108, 171-174; Carolle Carter, The Shamrock and the Swastika (Palo Alto: Pacific Books, 1977), 105-142; John Duggan, Neutral Ireland and the Third Reich (Totowa: Barnes and Noble, 1985), 148-150; John Duggan, Herr Hempel at the German Legation in Dublin 1937-1945 (Portland: Irish Academic Press, 20030, 139-141; Paul McMahon, British spies and Irish Rebels (Suffolk: Boydell Press, 2008), 195310; Robert Fisk, In time of War: Ireland, Ulster and the Price of Neutrality 1939-45 (London: Deutsche Brandon, 1983), 328-334.

73 Maria Georgiadou, Constantin Carathéodory Mathematics and Politics in Turbulent Times (Berlin: Springer Verlag, 2004), 278-341; Ulf Hashhagen, 'Ein griechischer Mathematiker als bayerischer Professor im Dritten Reich: Constantin Caratheodory (1873-1950) in München,' in 'Fremde' Wissenschftlicher im Dritten Reich: die Debye-Affäre im Kontext, ed. Dieter Hoffmann und Mark Walker (Göttingen: Wallstein Verlag, 2011), 151-173.

74 Rael D. Strous and Morris C. Edelamn, 'Eponyms and the Nazi Era: Time to Remember and Time to Change,' Medicine and Holocaust 9 (2007): 208; Ernst Klee, Das Personenlexikon zum Dritten Reich (Hamburg: S. Fischer, 2003), 277; Günther Wagner et al., ed., Enzyklopedia Medizingeschichte (New York: Walter de Gruyter New York, 2007), 658. 
His refusal to work for the German military led to his dismissal in September $1939 .{ }^{75}$ Fedor Stepun was born in Russia, he studied in Heidelberg. In 1926 he was appointed Professor of Sociology at the Dresden University of Technology. In 1937 he was no longer allowed to teach or publish in the Third Reich. ${ }^{76}$ Ebbe Neergaard was from Denmark. He had been lecturing English and German literature at the University of Berlin from 1928-1933. He was dismissed in 1933 for being a socialist. ${ }^{77}$

Stellen Arvidson was from Sweden. He taught Swedish at Kiel University from 1926 to 1930, thereafter at the University of Greifswald. He was dismissed in 1933 after criticizing National Socialism in a Swedish Socialist publication. ${ }^{78}$ Although Arvidson did not remain, any void his departure created was filled by others as there were instructors willing to conform to Nazism. Nordic Studies had already been expanding during the Weimar Republic, which only increased during the Nazi era. Scandinavia had primary sources on pre-Christian European culture, these sources played a role in the German identity prior to, and during the Third Reich. The Nazi affinity to Nordic culture created special opportunities for those academics that could accept fascist ideaology. Ake Ohlmarks earned his doctorate from the Univeristy of Lund, Sweden in 1937. His dissertation was compatible to Nazi ideology, plus he was anti-communist and anti-Russian. He lectured at the University of Tübingen from 1933-1934, University of Reykjavik, $1935^{-1936}$ and the University of Greifswald 1941-1945. Alexander Muten was educated at the University of Gothenburg, Sweden. He accepted a position in August 1932 as a Swedish lecturer at the University of Rostock. He remained at the University of Rostock for the duration of the

75 Martijn Eickhoff, In the Name of Science: P.J.W. Debye and his Career in Nazi Germany (Amsterdam: Aksant, 2008), 1-5; 36-116; Gijs van Ginkel, Prof. Peter J.W. Debye (1884-1945) in 1935-1945: An investigation of historical sources (2006), accessed March 8, 2016, http://www .theochem.ru.nl/ pwormer/Historical\%2osources\%2oDebye\%201935-1945.pdf.

76 A.F. Zweers, 'An Unpublished German Essay by Fedor Stepun on Ivab Bunin,' Germanico-Slavica 4, no. 5 (1984), 265; Kantor Vladmir, 'Daemonen versus Madonna: Dresden als magischer Kristall der russischen Probleme,' in Die Ost-West Problematik in den europaeschen Kulturen und Litaturen, ed. Diegfried Ulbrecht and Helena Ulbrechtova (Dresden: Neisse Verlag, 2009), 184.

77 Herbert G. Luft, 'Ebbe Neergaard,' Films in Review 8 (1957): 540; Donald Skoller, Dreyer in Double Action (New York: Dutton,1973), 200.

78 Louis Clerc, Nikolas Glover, and Paul Jordan, ed., Histories of Public Diplomacy and Nation Branding in the Nordic and Baltic Countries: Representing the Periphery (Leiden: Brill/Nijhoff, 2015), 29; Brita Stenholm, 'Stellan Arvidson und Greifswald,' Germanisten 3, no. 1-3 (1998): 86-88. 
Third Reich. He supported Nazi ideology and its aims during his time in Fascist Germany. 79

With Germany's annexation of Austria in March 1938 the University of Vienna fell under Nazi control resulting in both non-Aryan instructors and students being dismissed for political and racial reasons. From those dismissed it is known that some were foreign nationals were foreigners and viewed as being too liberal or politically unreliable. Many were discharged due to the Austrian Ministry of Education prohibiting certain instructors and professors from teaching at institutions of higher learning throughout Austria. This law became effective on 22 April 1938, mere weeks after the Anschluss. By mid-1938 at least ten foreign-born instructors from the University of Vienna were dismissed. ${ }^{80}$ Edmund Groag was born in the Czech Republic and was a Professor of Roman history at the University of Vienna. Although a practising Catholic he was persecuted as a Jew until he was dismissed from his position in 1938 . Alexander Issatschenko was born in Russia. He was an instructor for Russian at the University of Vienna. He was deemed as being politically unreliable and dismissed from the university on July 14, 1938. Heinrich Joseph was born in the Czech Republic. He was employed at the University of Vienna as a Professor of Zoology. He was fired from the University for being politically unreliable in 1938. He committed suicide in Vienna in January 1941. Nikolai Sergejewitsch Trubetzkoy was born in Russia. He had been a professor for Slavic Studies at the University of Vienna since 1922. He lost his position for being politically unreliable in 1938; he died the same year. Hans Tietze was born in the Czech Republic. He taught Art History at the University of Vienna, he was dismissed due to his political orientation in 1938. Wolfgang Pauli was born in the Czech Republic, he was professor for Biological-Physical Chemistry at the University of Vienna; he was dismissed for being politically unreliable in 1938. Richard Wasicky was born in Poland. He was professor of Pharmacology at the University of Vienna. He lost his position for his political orientation on April 22, 1938. Theodor Demetriades was born in Greece. He was a Paediatrician of Laryngology at the University of Vienna. He was dismissed for being politically

79 Anders Marrell, 'Ake Ohlmarks: schwedischer Lektor, Nazimitläufer und/oder Geheimagent,' Germanisten 3, no. 1-3 (1998): 93-97; Andreas Akerlund, Nordic Studies in National Socialist Germany: A Possible Career Path for Swedish Academics, accessed March 12, 2016, https://www.academia.edu/1900583/Nordic_Studies_in_National_Socialist_Germany_A_ Possible_Career_Path_for_Swedish_Academics.

$80 \quad$ Wolfgang Reiter, 'The Year 1938 and its Consequences for the Sciences in Austria,' in Vertreibung der Vernunft: The Cultural Exodus from Austria, ed. Friedrich Stadler and Peter Weibel, 2nd ed. (New York: Springer, 1995), 191-192. 
unreliable on April 22, 1938. Egon Brunswick was born in Hungary. He was an assistant lecturer for Psychology at the University of Vienna. He was dismissed for being politically unreliable on April 22, 1938. Johann Wilhelm Billiter was born in France. He was a Professor for Physical Chemistry at the University of Vienna. He was expelled from the University on April 22, 1938 for his French heritage..$^{81}$

\section{Hamilton after Nazi Germany}

It is simply unknown how many foreigners were intimidated into leaving Greater Germany. But in 1938 Hamilton deemed it time to leave. Prior to leaving Germany the Hamilton's gave Johanna's brother Hellmuth Jahn, power of attorney over their property in Berlin. ${ }^{82}$ In 1939 Hamilton had been formally declared Jewish by Nazi authorities with his name being officially listed as Louis Hamilton Silberberg. ${ }^{83}$ The Auslandshochschule glossed over Hamilton absence in 1939 by reporting that due to the outbreak of the war Hamilton remained in his homeland and could not resume teaching in Germany. ${ }^{84} \mathrm{Ham}-$ ilton's still had his property in Nazi Germany; the Hamilton house alone was estimated to be worth 34,200 Reichsmark in 1940. Unfortunately the house was totally destroyed in March 1944 through allied bombing. ${ }^{85}$

81 'Johann Wilhelm (Jean) Billiter (Billitzer),' Memorial Book for the Victims of National Socialism at the University of Vienna in 1938, accessed March 5, 2016, http://gedenkbuch.univie.ac.at/index.php? $\mathrm{L}=2$

82 BAB R 87/8869 51 M108 54: Anmeldebogen B, 22.IV.40 [Verwaltung des feindlichen Vermogen]; вАв R 87/8869 51 M108 54: Urkunderolle für 1938 Nr. 454, Dr. Jahl, Dr. Johanna Hamilton, October 4, 1938; BAB R87/8869 51 M108 54: Frau Hermine Wolff v. Schutter (geb. Jahn) an Reichskommissar beim Justizministerium, May 25, 1941; вАв R87/8869: Rechtsanwalt Max Baerwinkel an Reichskommissar für die Behandlung feindlichen Vermögens, April $18,1944$.

83 GSAP I Rep.208 Nr. 66: Arlt Geheime Staatspoleizei an das Orientalische Seminar der Universitaet Berlin November 30, 1939.

84 Clemens Scharschmidt, ed., Mitteilung der Ausland-Hochschule an der Universität Berlin (Berlin: Walter de Gruyter and Co, 1939), IV.

85 BAB R87/8869 51 M108 54: Anmeldebogen B, 22.IV.40 [Verwaltung des feindlichen Vermogen]; вАв R 87/8869 51 M108 54: Urkunderolle für 1938 Nr. 454, Dr. Jahl, Dr. Johanna Hamilton, October 4, 1938; вАв R87/8869 51 M108 54: Frau Hermine Wolff v. Schutter (geb. Jahn) an Reichskommissar beim Justizministerium, May 25, 1941; BAB R87/8869: Rechtsanwalt Max Baerwinkel an Reichskommissar für die Behandlung feindlichen Vermögens, April 18,1944 . The Hamilton house was rented to a married couple named Vaatz. 
Hamilton admired Germany, yet the nazified version of his land of residence and his negative experiences plus what he witnessed around him became problematic. Upon arriving in Britain Hamilton noticed how long he had been living abroad. Hamilton and his German born family had problems adjusting to British life. Throughout his life Hamilton was an apolitical figure, but in Britain he found employment working for the British against Nazi Germany. This may have been done for retribution not against Germany, but the corrupted version of Germany through Third Reich ideology and legislation. Possibly he may have felt that penance was due for working within the Nazi system and helping it both nationally and internationally during the early transitional years. Regardless Hamilton needed employment and he found work with the British Broadcasting Corporation (в ВС). He worked as German Language Intelligence Supervisor responsible for German ввс language broadcasts. The ввс began German language service in September 1938; this service was extended in January 1939. By April 1939 the в вС regularly used stronger anti-Nazi propaganda during its broadcasts. Unfortunately it is unknown precisely when Hamilton began working on the ввС's German language services as its staff lists did not include Hamilton in 1939; staff lists were not made in 1940 and 1941, Hamilton was listed in 1942. Hamilton performed his new vocation well as the ввС administration applauded his competence and professionalism as a translator and his sound knowledge of German. ${ }^{86}$

On 6 April 1944 Hamilton wrote to the University of Saskatchewan inquiring about the possibility of returning to Saskatoon as a university instructor hoping his previous work and contacts made would aid him in finding a compatible position in Saskatoon. Hamilton also wrote that he would be willing to work for the Canadian Broadcasting Corporation (СвС). Hamilton was unsuccessful in both cases. ${ }^{87}$ Hamilton resigned from his BвC position on 22 July 221945 to work for the Political Intelligence Department (PID) of the British

86 Asa Briggs, The BBC: The First Fifty Years (London: Oxford University Press, 1985), 144-145, 221-224; Gerard Mansell, Let Truth Be Told: 50 Years of BвC External Broadcasting (London: Weidenfeld and Nicolson, 1982), 57-59, 95-107, 147-166; Louis Hamilton, The BвC German Vocabulary (London: Longmans, Green and Co, 1947), III-VI; Gunda Cannon, ed., Hier ist England - Live aus London: das Deutsche Programm der British Broadcasting Corporation 1938-1988 (London: ввC, 1988), 27; Louis Hamilton, 'The British War Refugee,' Contemporary Review 161 (1942): $362-368$; University of Saskatchewan Archive, Pres. Papers Series II A-22: Hamilton to Dr. Thomsen, April 6, 1944.

87 University of Saskatchewan Archive, Pres. Papers Series II A-22: Hamilton to Dr. Thomsen, April 6, 1944. 
Foreign Office (BFO). ${ }^{88}$ During World War II the British government formed the Political Warfare Executive (PWE) for the purpose of foreign propaganda aimed at damaging enemy morale, and boosting the morale of local inhabitants within occupied countries. It was formed in August 1941, reporting to the BFO. Possibily this was when Hamilton first became employed with the ввС. The PWE included staff from the ввС, Ministry of Information, and the propaganda elements of the Special Operations Executive. The PWE was a secret department, when dealing with the outside world it used the covername PID. The main forms of propaganda were radio broadcasts, postcards, posters and leaflets. This propaganda effort was the last vital work Hamilton accomplished before his death. ${ }^{89}$

Hamilton's reputation in academic circles in Germany and Canada between the two world wars made him a respected figure in Canadian and German historiography. Although coerced to leave Germany, Hamilton left reluctantly because of obstructions the Nazi administration arbitrarily laid before foreign born instructors. The Nazi government coerced him to leave the country that he had resided in for decades and respected. Back in Britain Hamilton served his land of birth through psychological warfare techniques employed by the British government. Throughout his adult life Hamilton was pro-German admiring many aspects of German life and culture. But Nazi Germany deemed Hamilton a foreign element and unwanted within higher education. ${ }^{90}$ Hamilton like many others foreigner academics that had forged a life in Germany was pressured to leave by the Nazi regime and their racist ideology. Ten years after leaving his beloved Germany, Hamilton died on 4 September 1948. ${ }^{91}$

88 Louis North, ввс Written Archive to G. Grams, 26 June 2007; Asa Briggs, The History of Broadcasting in the United Kingdom Vol. III (London: Oxford University Press 1970), 35-36.

89 Ellic Howe, The Black Game: British Subversive Operations Against the Germans During the Second World War (London: Michael Joseph Press, 1982), 29-57; Charles Cruickshank, The Fourth Arm Psychological Warfare 1938-1945 (London: Davis-Poynter, 1977), 153-187.

$90 \quad$ Roberts and Tunnell, The Canadian Who's Who 1937, 469; Roberts, The Canadian Who's Who 1938, 298-299; Hamilton, The ввс German Vocabulary, III-VI; Hamilton, 'The British War Refugee,' $362-368$; G. Macklin, National Archive of the United Kingdom, to G. Grams, July 1, 2005; Louis Hamilton, 'Recording English Monuments,' The Times Literary Supplement, June 5, 1948, 317 . 